\title{
Preservation of Local Language Culture in Toundanouw Village District Southeast Minahasa Regency
}

\author{
${ }^{1}$ Veronika E. T. Salem* \\ Sociology Education Study Prgram \\ Social Science Faculty \\ Universitas Negeri Manado \\ Tondano, Indonesia \\ veronikaetsalem@gmail.com
}

\author{
${ }^{2}$ Romi Mesra \\ Sociology Education Study Program \\ Universitas Negeri Manado \\ Tondano, Indonesia \\ romimesra@unima.ac.id
}

\begin{abstract}
The research problem is to study the preservation of local language culture in Toundanouw village Southeast Minahasa. Where the younger generation rarely communicates using their own native language. By using a qualitative research method to explain the problems to be studied with participatory observation and interview techniques. It can be concluded parents is lack of explaining or teaching the local language itself and the school does not teach local languages.
\end{abstract}

Keywords - Preservation, local Language, culture

\section{INTRODUCTION}

Local languages in Indonesia have an influence on the formation and development of Indonesian. Before becoming familiar with the Indonesian language, most Indonesians learned and used local languages in the interaction of people's lives. Words and ways of conveying ideas are influenced by the habits commonly used by the community [1]. Regional languages are still maintained by the state as part of a living culture. Tounsawang is the native language of the Tombatu region, especially in the village of Toundanouw, Toulagai District, Southeast Minahasa Regency. Culture of a nation in the world. According to Koentjaraningrat, there are seven elements of universal culture, namely: Language, Knowledge Systems, Social Systems or Social Organizations, Living Equipment and Technology Systems, Living Livelihood Systems, Religious Systems and Arts

Language is a part of universal culture has an important role to determine the quality of a nation. To communicate using a language is an understanding and response we provide in the form of command sentences, news, questions, answers, and others. However, there are people who think that the competence of using language seems to be achieved perfectly through heredity and inheritance. Tounsawang Language as the language of the Tombatu region Touluaan District is a part of the Minahasa language. However, currently is rarely used in the community or in daily life in the village of Toundanouw atas, Touluaan District, Southeast Minahasa Regency.
The community is expected to be able to preserve their local culture and always play an active role in the development of the region itself, due to the community is the key to the development of an area. Reference [2] assumes development as an effort to achieve prosperity, and of course, the contribution of youth is in it. The contribution of youth in bringing positive change to the nation to create the next generation. The character of young people who are physically strong and creative is highly expected for the nation's development.

If it is combined with mental resilience and a spirit of development and optimism that is welling up, it would be the right package to strive for the change and progress of the aspired nation. The revolution to Indonesian brought the flow of change and progress of the Indonesian people, especially freedom of expression which until now can be enjoyed, is one of the concrete manifestations of the role of youth as the driving force. For many parties, including the government, it is natural seriously striving for national development is not from an established (adult) group but from young people who have the potential to develop. The role of youth is also included in the role of maintaining local cultural wisdom such as language culture.

Culture is inherent in society and has been hereditary for a long time, which will be increasingly conceptualized in people becomes a belief in matters relating to a belief that is difficult to dispel. The beliefs are developing in the life of a community which usually maintained through the local characteristics they have. Where the local nature eventually becomes wisdom that always held by the people.

The community is expected able to create new creations to advance an area, but in fact, they are lulled by advancing technological advances. With this, young people become passive to the culture owned by their regions which should be their responsibility to preserve and maintain values -the value contained therein. 


\section{RESEARCH METHODS}

The method used in this research is a qualitative method. According to reference [3] that qualitative research methods are research methods based on the philosophy of positivity used to examine natural conditions of objects, where researchers are the key instruments. The subjects in this study were the people of the village of Toundanow Atas Toulamor District, Southeast Minahasa Regency. The techniques used in collecting data in this study are Observation of Participation. Analysis of the data used by the authors is qualitative data analysis [4].

\section{RESULT AND DISCUSSION}

Preservation of regional language culture in Toundanow Atas Village, Toulagai District, Southeast Minahasa Regency is still lacking. This can be seen based on the results of research that in general the people in the village of Toundanouw have been contaminated with a new culture that tends to affect the daily use of language. In general, people and facilitators no longer use regional languages in life but instead use modern languages that are considered sociable by young people. The role of parents is very much needed in the preservation of the language culture of the Upper Toundanow region, Toulagai District, Southeast Minahasa Regency. But based on the results of the study showed parents do not teach children about local languages as a daily language.

Culture is a complex whole, which contains knowledge, beliefs, arts, morals, laws, customs, and other abilities, and habits which obtained by humans as members of society [5]. Soemardjan and Soemardi ini reference [6] formulated, culture as all the works, tastes and inventions of the people. Community works produce material and material culture or material culture that is needed by humans to master the natural surroundings so that the strength and the results can be devoted to the needs of society. The role of the government is very needed in the process of preserving local language culture in Toundanow Atas Village, Toulagai District, Southeast Minahasa Regency, based on the results of the study shows that the role or effort of the government in preserving regional language culture is not available yet. The role of the school is lack preservation of local language culture due to local languages are not included in the curriculum at school, students prefer to use modern languages. The community in English terms is "society" comes from the Latin word means socius (friend). The term society comes from the Arabic word syaraka which means (to participate). Society is a group of people who get along with each other, in scientific terms it is interacting with each other. A human unit has infrastructure through which its citizens can interact with each other. Another definition, society is the unity of human life that interacts according to a particular system that is continuous and bound by a sense of shared identity. Society is a community unit that has all four characteristics, namely: 1) Interaction between its citizens, 2). Customs, 3) Continuity of time, 4) A strong sense of identity that binds all citizens [7].

The system of living together gives rise to culture because each group member feels bound to one another [6]. Some opinions of the experts above can be concluded that the community means to participate or participate, whereas in English it is called society. It can be said that society is a group of people who interact in a social relationship. They have similarities in culture, territory, and identity, have habits, traditions, attitudes, and feelings of unity that are bound by similarity.

The Tonsawang language is one of the languages spoken in the area around Tombatu, Southeast Minahasa, North Sulawesi. The Tonsawang language is included in the Minahasa language family. Formerly the use of the Tonsawang language was a reflection of the culture and identity of the Tonsawang people who were residents of the Tombatu (Tombatu Raya) area. Tombatu residents in the south of Mount Soputan. The Tonsawang language is heavily influenced by other Minahasa languages such as Tountemboan and Tombulu. This can be seen through the similarities in the vocabulary of the Tonsawang language and other Minahasa languages.

The arrival of foreign nations such as Spain, the Netherlands, and Japan did not significantly affect the existence of the use of the Tonsawang language in the past. However, the centralization of the use of Indonesian in the New Order greatly influenced the use of the Tonsawang language. In its development entering the globalization and modernization era which is full of advances in science and technology, has helped change the pattern of life and communication of many people including children of the Tonsawang tribe. This is not only experienced by young people but is endemic to adults. Unwittingly, the Tonsawang language has begun to erode the flow of globalization with the tendency of generations to speak languages that are not organized in a good culture.

\section{CONCLUSION}

Based on the above research conclusions, the researcher can submit a number of suggestions according to the needs in the field, which are as follows: There needs to be a role for the government in the preservation of regional language culture in the Village of Toundanouw Atas, Toulagai District, Southeast Minahasa Regency.

\section{ACKNOWLEDGMENT}

The author would like to acknowledge the Dean of Faculty of Social Science, Manado State University in supporting the publication of this article. 


\section{REFERENCES}

[1] Aminuddin, Semantik Pengantar Studi Tentang Makna. Bandung: Sinar Baru Algensindo, 1985.

[2] Koentjaraningrat, Masalah Kesukubangsaan dan Integrasi Nasional. Jakarta: UI Press, 1993.

[3] Sugiyono, Metode Penelitian Kombinasi (Mixed Methods). Bandung: Alfabeta, 2016.

[4] L. J. Moleong, Metodologi Penelitian Kualitatif. Bandung: Remaja Rosdakarya, 2011.

[5] J. Ranjabar, Sistem Sosial Budaya Indonesia Suatu Pengantar. Bandung: Galia Indonesia, 2013.

[6] S. Soekanto, Sosiologi suatu pengantar. Jakarta: Raja Grafindo Persada, 2012.

[7] Koentjaraningrat, Pengantar Ilmu Antropologi. Jakarta: Rineka Cipta, 2002. 